\title{
TERMS OF DEVELOPMENT OF MULTIMODAL TRANSPORTATION FORMING AN ALTERNATIVE TECHNICAL BASIS OF RAILWAY TRANSPORT
}

Summary. Multimodal transportation involves the use of several types of transport in the transport of one cargo. It is carried out under the condition of unity of the commercial legal regime, therefore customs procedures are simplified. In this article the modern state of the material and technical base of railway transport for the implementation of multimodal transport is analyzed. During the study, the main obstacles and requirements for the development of multimodal transport equipment were identified. The article deals with the main players in the market of transport engineering. Also described possible technologies for the implementation of multimodal transport. The expediency of using non-wagon technologies for the development of multimodal transportation in Ukraine is substantiated.

Keywords: multimodal transportation, railway transport, transport engineering, rolling stock, material and technical base.

Варава І.М., Шевченко Ю.В. Національний авіаційний університет

\section{УМОВИ РОЗВИТКУ МУЛЬТИМОДАЛЬНИХ ПЕРЕВЕЗЕНЬ ПРИ ФОРМУВАННІ АЛЬТЕРНАТИВНОЇ ТЕХНІЧНОЇ БАЗИ ЗАЛІЗНИЧНОГО ТРАНСПОРТУ}

\begin{abstract}
Анотація. Організація перевезень різних вантажів є одним з основних напрямків роботи багатьох компаній. Відповідно до виду транспорту, який бере участь в доставці вантажів, всі перевезення ділять на одновидові (юнімодальні) та багатовидові (мультимодальні). Мультимодальне перевезення є більш складною $з$ точки зору оформлення юридичних документів і організації всіх видів робіт. Даний тип доставки передбачає використання декількох видів транспорту в транспортуванні одного вантажу. Це може бути залізничний, автомобільний, авіаційний, морський транспорт. При цьому, організація робіт здійснюеться за єдиним перевізним документом. Перевантаження товарів, що здійснюеться в ході доставки різними видами транспорту, відбувається без будь-якої участі клієнта. Мультимодальні перевезення здійснюються за умови едності комерційно-правового режиму, тому митні процедури спрощуються, уніфрікуються документи на доставку як всередині однієї країни, так і при використанні міжнародних рейсів. Відмінна риса всіх мультимодальних перевезень - комплексний підхід до вирішення всіх завдань. Саме завдяки цьому компанія-виконавець має можливість швидко і без будь-яких технічних проблем здійснювати роботи, мінімізуючи терміни та істотно знижуючи загальну вартість. Вдається заощадити гроші й час, які витрачаються на консолідоване транспортування, в порівнянні з організацією ряду окремих перевезень, які б виконувалися різними операторами. Сучасні залізничні вантажоперевезення - це надійний та швидкий спосіб переміщення значних обсягів вантажу на далекі відстані. За допомогою залізниці можна перевозити будь-які вантажі: великі, довгомірні, негабаритні, масові й вантажні, які потребують особливих умов зберігання та транспортування.. Склад поїзда дозволяе причепити до нього будь-яку кількість вагонів, контейнерів або цистерн. Транспортування вантажів за допомогою залізниці може здійснюватися в будьякий час року, незалежно від погодних умов. Саме тому залізничні вантажоперевезення так популярні і ефективні. У даній статті проаналізовано сучасний стан матеріально-технічної бази залізничного транспорту для здійснення мультимодальних перевезень. Під час дослідження виявлені основні перешкоди та вимоги до розвитку техніки для мультимодальних перевезень. В статті розглянуті основні гравці на ринку транспортного машинобудування. А також охарактеризовано можливі технології здійснення мультимодальних перевезень. Обгрунтовано доцільність використання безвагонних технологій для розвитку мультимодальних перевезень в Україні.
\end{abstract}

Ключові слова: мультимодальні перевезення, транспортне машинобудування, рухомий склад, матеріально-технічна база, залізничний транспорт.

$\mathrm{F}$ ormulation of the problem. Today, multimodal transportation is becoming a priority area of Ukraine's transport policy. Thus, at the initiative of the Ministry of Infrastructure of Ukraine, the "Strategy for the development of multimodal transport" and the draft law "On Multimodal (Combined) Transport in Ukraine" are being developed $[1 ; 2]$. The efficiency of multimodal transportation is achieved through the improvement of various forms of coordination: technical, technological, economic, organizational, managerial and economiclegal.

Analysis of recent research. Issues of multimodal traffic for a long time paid considerable atten- tion to many scientists in the world and in Ukraine. They were engaged in clarification of the conceptual apparatus of multimodal transport. Considered the aspects of organizing and managing multimodal transport, as well as increasing their efficiency. But only today in our country are formed the necessary legislative conditions for their development.

Identification of previously unsettled parts of the general problem. Multimodal international transportation performed by two or more modes of transport is organized by the operator, who assumes the responsibility of delivering cargo "from door to door" under a single agreement and through the freight rate [3]. 
Despite its efficiency, multimodal transportation is very costly. This is primarily due to technological and technical re-equipment. But the issue of the interconnection of existing technical capabilities of multimodal transport and the analysis of sources of production of the necessary equipment in the work of scientists is given insufficient attention.

The purpose of the article. In this regard, the purpose of the article is to analyze alternative solutions for the formation of the technical basis of rail transport in the development of multimodal transport.

The task of technical equipment of multimodal transportation can be solved by the cooperation of rail transport with domestic producers. There are different technologies of multimodal transportation, and accordingly different types of vehicles are used. Currently, container transportation is the most widespread in Ukraine. Currently, on the balance of the UTSTSTS "Liski" is 4.506 thousand containers, of which 2048 - 20-feet and 2458-40feet. "Liski" carries about 40\% container cargoes. Others are transported in containers of sea lines or their own CIS countries [4].

In Ukraine, an extensive system of container trains and combined transport trains is operating in the direction of Asia, Central and Eastern Europe, Scandinavia and the Baltics. Thus, 2 trains of combined transport, 14 container trains and 4 trains by route groups constantly travel on the territory of Ukraine. Ukraine also initiates the organization of the movement of the piggyback train in the direction of Italy-Austria-Hungary-Ukraine and further to the East.

However, the tendencies that characterize the work of the railway transport, connected with the accession to the European Union, create certain restrictions for manufacturers, forcing the latter to meet certain requirements. So the decision of the 59 th session of the Council on the railway transport of the member states of the Commonwealth from the first of January 2014 discontinued use of medium-tonnage containers with exhausted normative term of operation in international traffic. Requirements for rolling stock are constantly increasing. After the entry into force of Directive 2008/57 / EC, all trains operated on national rail networks of Europe must comply with the set of technical requirements for interoperability developed by the European Railway Agency.

The transport strategy of Ukraine for the period until 2020 also envisages the introduction of vehicles, service, technical, economic performance which meet the current European requirements for safety, environmental and energy efficiency of transport.

Given the increased interest in multimodal transport in the EU and Ukraine, growth in demand for the respective vehicles can be expected. This applies to both wagons and traction rolling stock. The forecast of UNIFE studies also confirms the growing demand for rail industry products and services in Latin America, Africa and the Middle East by 2017. This is due, among other things, to the growth of freight volumes. Thus, according to the forecast of the SRI Verkehr, by 2020, global rail freight traffic may reach 14.7 trillion $\mathrm{t}-\mathrm{km}$, which is $50 \%$ more than in 2010 [5].

Since the publication of the results of the World Rail Market 2010 research, there has been a steady growth of the global market: according to the estimate Roland Berger, his annual cost is approaching 146 billion euros. The largest are sectors of the mobile warehouse and service, they account for their share $71 \%$ of the market.

In 2015-2017 years are projected growth of the railway industry in all regions with an average rate of $2.6 \%$ per year. Ukrainian enterprises are engaged manufacturing rolling stock that Used for multimodal transportations, in particular containers. However recently due to the crisis in their country cases have become much worse due to orientation products to a greater extent on the Russian market.

Among the domestic producers should be noted Kryuk carriage building factory, Azovmash. Despite the great opportunities for development domestic railway industry, Ukrainian Industrialists are in serious competition with the part of foreign manufacturers. Yes, the main thing manufacturer of cargo containers for international transportation is now China, where produce containers of all types. One of them The leading companies here are China International Marine Containers Group, whose purpose is to provide consumer wide spectrum high-tech products at the lowest price. It is not possible to compete in this segment. IN connection with domestic producers it is necessary look for your own niche in the manufacturing market vehicles.

Consider the features of such a moving a warehouse that can create an alternative container transportation. Because the most common in the implementation of multimodal Transportation is the interaction of rail transport with automotive, we will focus on the analysis technologies used in it.

In addition to container transportation, the interaction rail and road transport recently implemented on a basis the introduction of piggyback and roducer transportation Container transportation provides transportation on the trailer platform, semi-trailer or towed body (TOFC), as well also transportation to low-floor railways car chassis platforms with installed Containers on them (COFC) [6].

The widespread they got in USA. Adopted on European railways cargo dimensions are assumed to be maximum value for the height of the car with the intermodal the transport unit $-4.18 \mathrm{~m}$ (dimension $\mathrm{B}+$ ). Therefore, piggyback transportation (TOFC) can run on a limited number of routes or require work to increase high-altitude dimensions.

For the use ofcontainer transportations were created railway platforms with holes (pockets) in the bottom, where the wheels are lowered trains This technology has received the name of the "running highway". Transportation can to be carried out with or without the driver. However, this technology increases weight through the necessity of transportation of a tractor, a semitrailer and driver for whom you need to create the appropriate ones conditions during travel. used for transportation of goods in difficult to reach areas when travel by rail tunnels more economical, than mountain roads.

Technology of transportation of "bodies that removed "was widely distributed in Europe. Its advantage is the lightness of the body and the smaller overall height. The disadvantage is impossibility body stacking and insufficient protection Cargo due to low body strength. For them transportation on 
the chassis requires special devices Bodywork can not be considered in a few Tiers and therefore take up a lot of space on the terminal.

Thus the drawbacks of the piggyback transportation is:

- transportation of significant non-commodity weight - a tractor, a trailer or a semitrailer;

- impossibility of stacking in several Tiers in the transport of trailers and bodies that are removed, both during the movement and at the terminal;

- insufficient cargo security through low body strength;

- the need for special use devices: bridge cranes and platforms for overload of trailers;

- the inability to use the technology TOFs on most European railways through dimensions of bridges, tunnels, height of suspension lines electricity supply investment.

Except wagon technology in there are also multimodal traffic non-wagon: roducer or bimodal. Such technology has become widespread in the United States in 80-90 years. Various options are known in Europe RoadRailer systems, including: Kombitrailer, Trailerzug, Transtrailer Semirail, etc.
Use of similar technology in America has made it possible to lower its cost transportation by $7.6 \%$ per one mile way and shorten the delivery time from 6 to 3 days.

The advantages of free-of-charge technologies are:

- inexpensive servicing of the mobile warehouse on terminals;

- the possibility of a large location number of reloading points in immediate proximity to the consumer through low cost of such terminals. The simpliest terminal is a gravel section between railways.

-3) the possibility of reducing losses and damage because there is no need for intermediate ones overloads;

-4) lower investment compared to TOFC;

-5) increase of speed of transportation.

However, in them a greater mass of tare movable warehouse, so in terms of development Multimodal transportation in Ukraine is expedient use non-wagon technology. They can provide greater profitability transport services, which is very important in the conditions limited financial capacity, and have more maneuverability in terms of location terminals.

\section{References:}

1. Sokolova O.Ye. (2014). Teoretichni osnovi organizatsiyi multimodal'nih perevezen v Ukraini [Theoretical foundations of organizations and development of multimodal transportation in Ukraine]. Ekonomichny prostir, no 1(83), pp. 91-103.

2. Katkevich G. Multimodalniye pyeryevozki [Multimodal transportation]. Transport. URL: http://transport-journal.com/ komentarii-obzori/multymodalnyie-perevozky

3. Pinchuk A. Neobhodimost uregulirovaniya multimodal'nih pyeryevozok d Ukrainye na zakonodatyel'nom urovnye [The need to regulate multimodal transportation in Ukraine at the legislative level]. Transport. URL: http://transport-journal.com/komentarii-obzori/neobhodymost-urehulyrovanyya-multymodalnyih-perevozok-v ukrayne-na-zakonodatelnom-urovne/

4. Belyaev V.M. (2014). Organizatsiya avtomobil'nih pyeryevozok i byezopasnost' dvizheniya [Organization of road transport and traffic safety].

5. Pinchuk A. Dlya EU multimodalniye pyeryevozki konteynyerov - naibolee effektivnıy, I bistriy sposob dostavki gruzov [For the EU, multimodal transportation of containers is the most efficient, environmentally friendly and fast way to deliver goods] // Transport. URL: http://transport- journal.com/komentarii-obzori/dlya-es-multymodalnyieperevozky

6. Pinchuk A. (2011). Tendentsiyi mirovogo rinka zheleznodorozhnih pyeryevozok [Trends in the global rail market]. Zhelezniye dorogi mira, no 7, pp. 56-75. 